\title{
Structural Characterization of Substituted Calcium Titanate Compounds $\mathrm{Ca}_{1-\mathrm{X}} \mathrm{La}_{\mathrm{X}} \mathrm{Ti}_{1-\mathrm{x}} \mathrm{Fe}_{\mathrm{x}} \mathrm{O}_{3}$
}

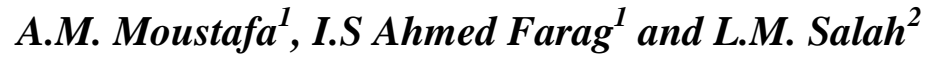 \\ ${ }^{1}$ Physics Department, National Research Centre, Dokki, Cairo, Egypt. \\ ${ }^{2}$ Physics Department, Faculty of Science Cairo University.
}

The title compounds $\mathrm{Ca}_{1-x} L a_{x} \mathrm{Ti}_{1-x} F \mathrm{Fe}_{x} \mathrm{O}_{3}(0.0 \leq x \leq 0.5)$ were prepared by solid state reaction at $1350^{\circ} \mathrm{C}$ for 24 hours. X-ray powder diffraction measurements were performed by step scanning mode.All the prepared samples were single phase of perovskite orthorhombic system and belong to the space group Pbnm. The crystal structure has been refined by Rietveld method using FULLPROF program. The exact coordinates of atoms, the unit cell dimension, isotropic temperature factors and the profile width parameters as well as the interatomic distances have been refined. It was found, that the unit cell parameters are related to the ideal perovskite cubic system and vary linearly with the cation substitution. The calculated values of the tolerance factor $(t)$ for these compositions indicate a significant degree of distortion in the perovskite structure. The distortion decreases with increasing the substitution and maximum distortion corresponds to $\mathrm{CaTiO}_{3}$, which is consistent with the experimental results of cell distortion factor. Also, from the refined values of the crystallite size, it was found that the crystallite size increases with increasing the substituted cations.

\section{Introduction:}

Perovskite-type oxides of general formula $\mathrm{ABO}_{3}$ [1] are important in material sciences, physics and earth sciences, for their electric properties and as a dominant mineral in the Earth's lower mantle. They are also well known for their phase transitions, which strongly affect their physical and chemical properties. The ideal perovskite structure of these compounds has been described as cubic, with 12-fold coordinated A ions at the corners, 6-fold coordinated B ions at the body centers and 6-fold coordinated B-ions at the face centers of the unit cubes. 
Calcium titanate, $\mathrm{CaTiO}_{3}$ is a perovskite structure having orthorhombic symmetry [2]. Sasaki reported [3], that the structure was orthorhombic at room temperature and transforms to the cubic ideal perovskite at high temperature, with an intermediate tetragonal phase [4-6]. Also, phase transition from orthorhombic to tetragonal and cubic symmetry has been reported with increasing $\mathrm{Fe}$ content at room temperature in the system $\mathrm{CaFe}_{\mathrm{x}} \mathrm{Ti}_{1-\mathrm{x}} \mathrm{O}_{3-(\mathrm{x} / 2)}$ for $0.0 \leq x \leq 0.4$. Thus, for $x \leq 0.205$ the structures are orthorhombic and for $x \geq 0.251$ they are cubic, the intermediate compositions showing tetragonal symmetry [7].

Kim et al. [8] reported, that in $\mathrm{CaTiO}_{3}$ the partial substitution of $\mathrm{Ca}^{2+}$ with $\mathrm{La}^{+3}$ leads to the formation of single phase $\mathrm{Ca}_{1-\mathrm{x}} \mathrm{La}_{2 \times / 3} \mathrm{TiO}_{3}$ solid solution with structural changes from orthorhombic to tetragonal double layered perovskite as $\mathrm{x}$ increases. Extensive study $[9,10]$ has been carried out on $\mathrm{CaTiO}_{3}$ to improve its dielectric properties indicating that on replacing divalent calcium by trivalent Yittrium or other rare earth ions, the charge neutrality is maintained by creating an appropriate number of vacancies on calcium sites. On other hand, Lewis and Callow [11] have reported, that donor substitution on A-site will lead to the formation of titanium vacancies to maintain electrical charge neutrality, while the acceptor dopant such as $\mathrm{K}^{+}$and $\mathrm{Fe}^{3+}$ will generate oxygen vacancies [12].

The aim of the present work is to study the effect of the substituting cations $\mathrm{La}^{3+}$ and $\mathrm{Fe}^{3+}$ on the structural characteristics of the compounds with the chemical formula $\mathrm{Ca}_{1-\mathrm{x}} \mathrm{La}_{\mathrm{x}} \mathrm{Ti}_{1-\mathrm{x}} \mathrm{Fe}_{\mathrm{x}} \mathrm{O}_{3}$, where $0.0 \leq \mathrm{x} \leq 0.5$.

\section{Experimental Work:}

Powder samples of general formula $\mathrm{Ca}_{1-\mathrm{x}} \mathrm{La}_{\mathrm{x}} \mathrm{Ti}_{1-\mathrm{x}} \mathrm{Fe}_{\mathrm{x}} \mathrm{O}_{3}(0.0 \leq \mathrm{x} \leq 0.5)$ were prepared by conventional solid state reaction from stoichiometric amounts of commercial products $\mathrm{CaCO}_{3}(99.99 \%), \mathrm{TiO}_{2}(99.99 \%), \mathrm{La}_{2} \mathrm{O}_{3}(99.999 \%)$ and $\mathrm{Fe}_{2} \mathrm{O}_{3}(99.99 \%)$. The starting materials in appropriate ratios were mixed well using agate mortar and pressed into pellits under pressure of $12 \mathrm{ton} / \mathrm{cm}^{2}$. They were first heated at $1000{ }^{\circ} \mathrm{C}$ for 6 hours. The presintered samples were ground to very fine powder and pressed again, then were heated at $1200{ }^{\circ} \mathrm{C}$ for 24 hours and the process of grinding and pressing was repeated. Finally, the samples were heated at $1350{ }^{\circ} \mathrm{C}$ for 24 hours. These heating treatments were followed by a natural cooling step in the furnace.

Powder X-ray diffraction data were collected on computer controlled X-ray diffractometer (formally made by Diano corporation, USA) using step 
scanning mode and filtered $\mathrm{CoK}_{\alpha}$ radiation $(\lambda=1.79026 \AA)$. The scanning range was $25-100^{\circ}(2 \theta)$ with step size $0.02^{\circ}(2 \theta)$ and counting time $5 \mathrm{~s} /$ step.

\section{Results and Discussion:}

Preliminary X-ray diffraction data revealed, that the prepared compounds consist of single phase perovskite structure. The diffraction lines shown in Fig.(1) are completely matched with JCPDS card number (81-0562) and the absence of the characteristic X-ray diffraction lines of the constituent oxides or other phases confirms the existence of one phase. All the diffraction patterns were indexed using the trial and error (Treor) [13] program to calculate the accurate unit cell dimensions and they were found to be related to perovskite orthorhombic system.

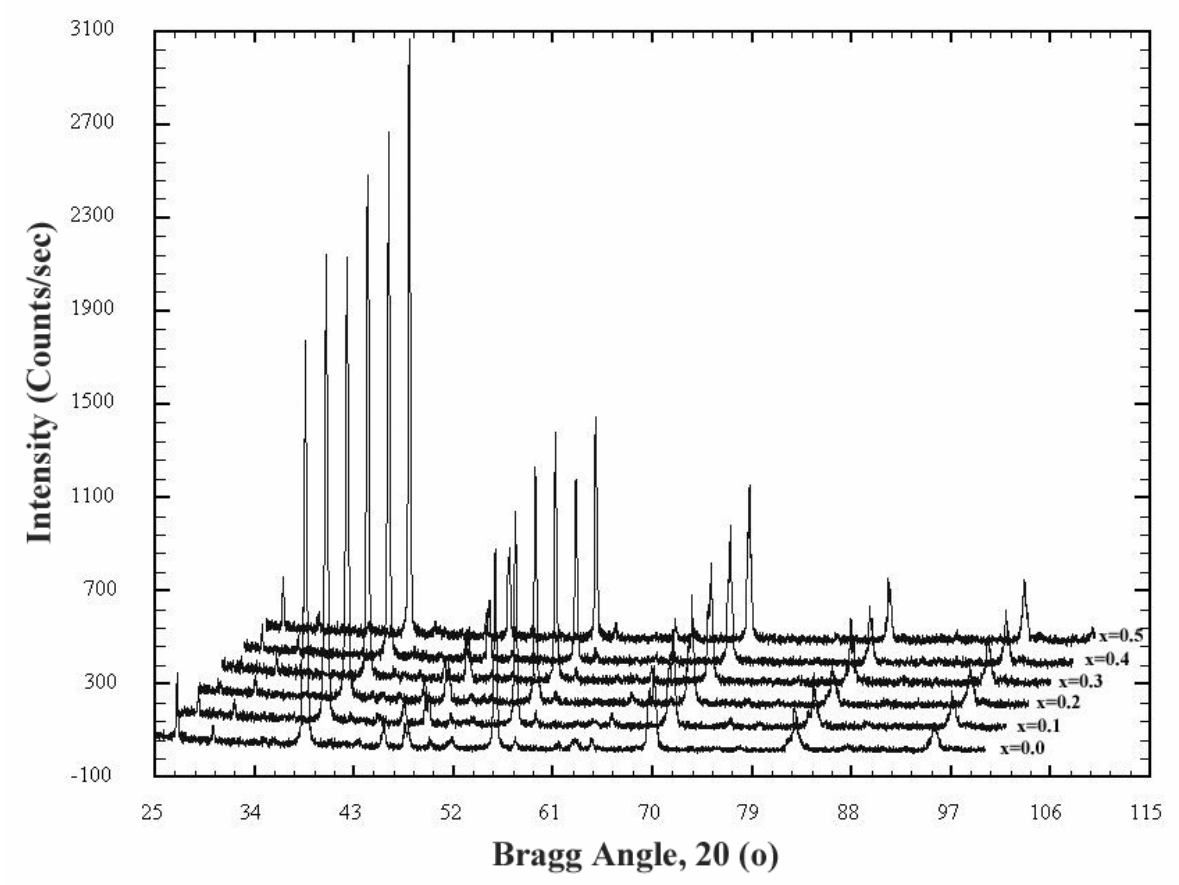

Fig.(1): X-ray powder diffraction pattern for the samples $\mathrm{Ca}_{1-\mathrm{x}} \mathrm{La}_{\mathrm{x}} \mathrm{Ti}_{1-\mathrm{x}} \mathrm{Fe}_{\mathrm{x}} \mathrm{O}_{3}$, $0.0 \leq x \leq 0.5$.

\subsection{Structure Refinement:}

The structure refinement was started by the determination of the instrumental constants, zero shift and instrumental profile. These constants have been determined using a standard annealed Quartz sample delivered from Diano corporation. A step scanning mode has been carried out on the 
investigated samples with exactly the same conditions conducted for the standard one. FULLPROFF software program [14] (version-LIB-JRC) for the structure refinement is used for Rietveld whole pattern fitting method. The starting model was that of $\mathrm{Gd}_{2} \mathrm{O}_{3}$ [15] of space group Pbnm (no. 62, cab nonstandard setting of Pnma) and $\mathrm{Ca}$ and La cations occupies (4c) $(\mathrm{u}, \mathrm{v}, 0.25)$, with $\mathrm{u}=-0.018, \mathrm{v}=0.06$, $\mathrm{Ti}$ and $\mathrm{Fe}$ occupies $(4 \mathrm{~b})$ at $(0.5,0,0)$, and oxygen anions occupies the positions $(4 \mathrm{c})$ with $\mathrm{u}=0.05, \mathrm{v}=0.47$ and $(8 \mathrm{~d})(\mathrm{x}, \mathrm{y}, \mathrm{z})$ with $\mathrm{x}=-0.2$, $\mathrm{y}=0.275, \mathrm{z}=0.05$. The experimental profile was fitted by modified THOMPSON COXHASTING PESUO-VOIGT function [16].

In the first step of the structure refinement, the global parameters (background, profile asymmetry, specimen displacement) were refined. In the next step, the structure parameters (atomic coordinates, specimen profile breadth parameters, lattice parameters, temperature factors, preferred orientation and site occupancy) were refined in sequence mode. When the discrepancy factor $R_{W P}$ ( $R$ - weighted pattern) has reached its minimum value, all the parameters (global and structural were refined simultaneously giving the goodness of fit index, $\chi^{2}=\left(\mathrm{R}_{\mathrm{WP}} / \mathrm{R}_{\mathrm{exp}}\right)^{2}$ in the range $(1.09-1.27)$. These values indicate a reliable refined structural parameters. The agreement between the observed and the calculated diffraction profiles of the sample with $\mathrm{x}=0.0$ and $\mathrm{x}=0.5$ as representative examples of the investigated compounds are shown in Fig. (2 and 3).

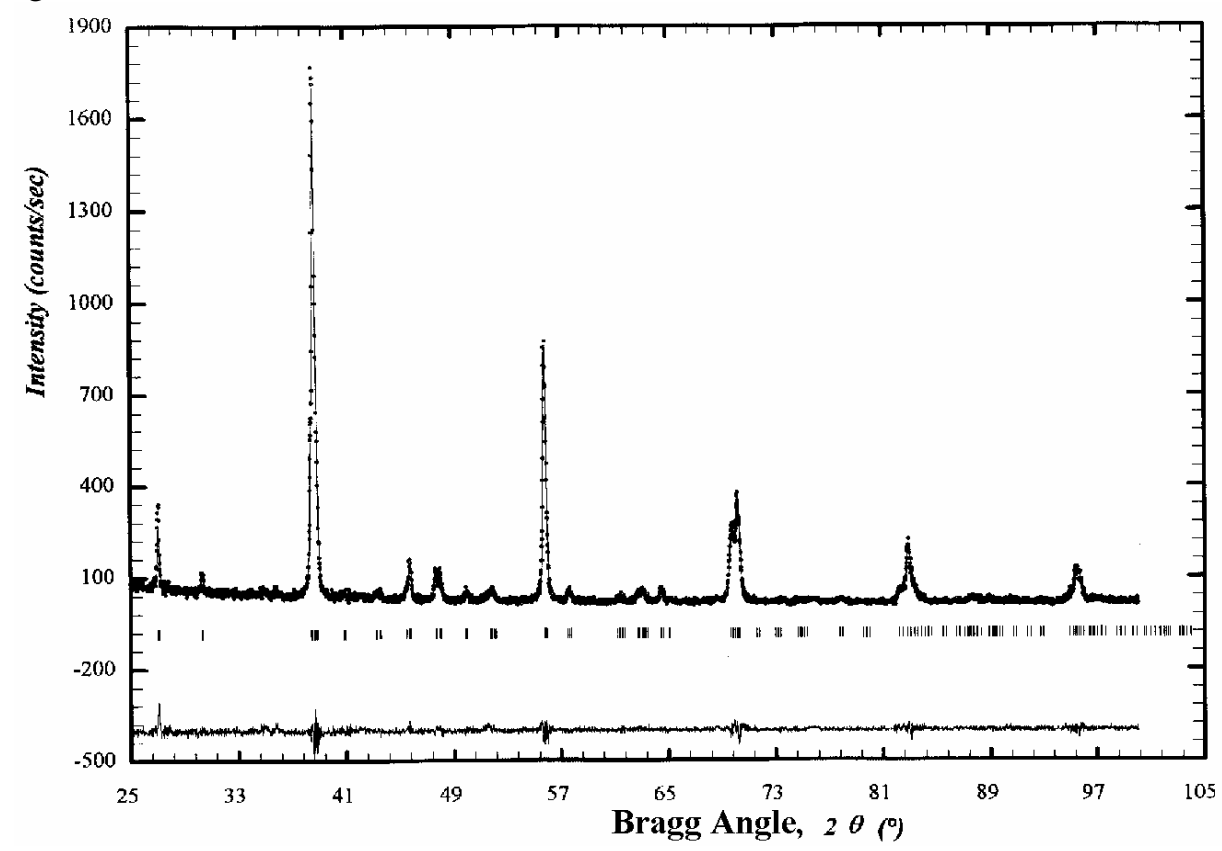

Fig.(2): The experimental and calculated X-ray patterns as well as their difference for the sample $\mathrm{CaTiO}_{3}$. 


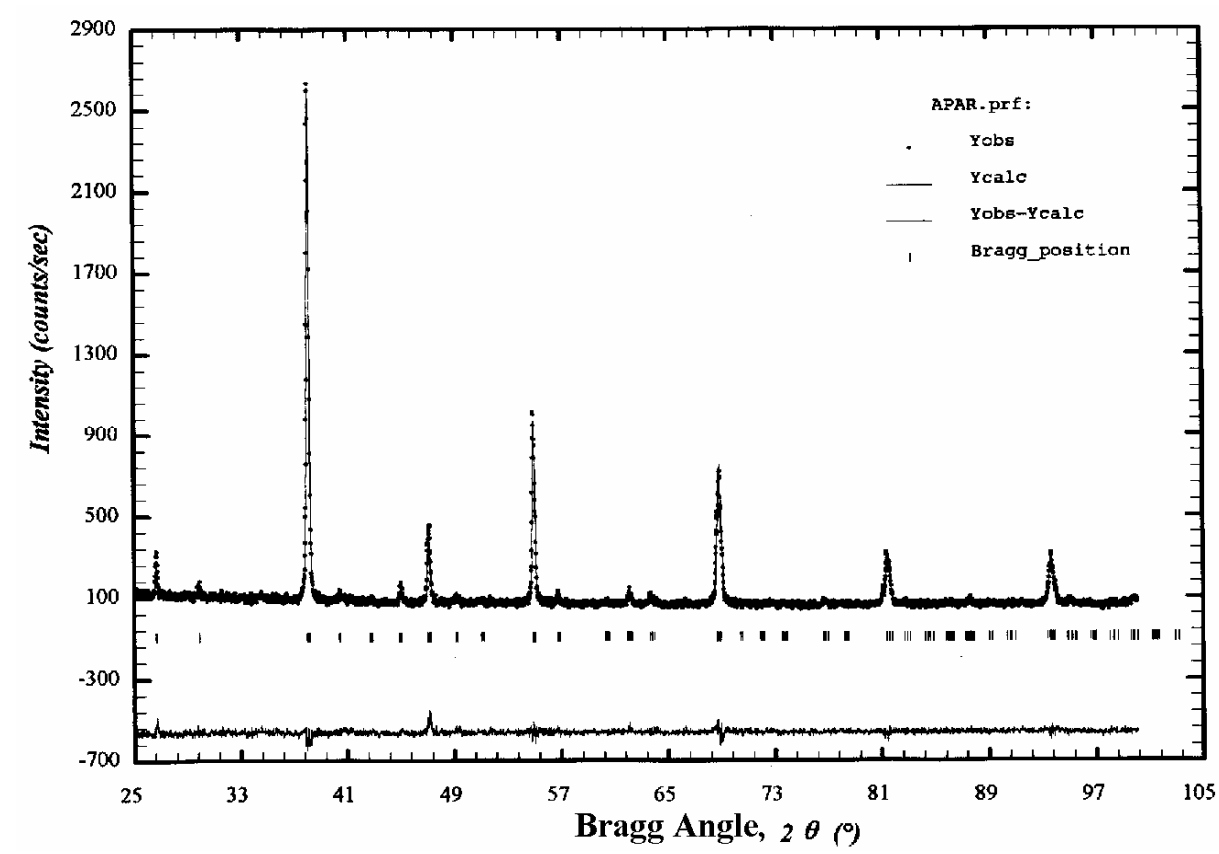

Fig.(3): The experimental and calculated X-ray patterns as well as their difference for the sample $\mathrm{Ca}_{0.5} \mathrm{La}_{0.5} \mathrm{Ti}_{0.5} \mathrm{Fe}_{0.5} \mathrm{O}_{3}$.

\subsection{Lattice Parameters and Structure distortion:}

Table (1) represents the variation of the lattice parameters with $\mathrm{x}$ parameter, given in the chemical formula of the compounds. It is clear, that the lattice parameters increase with increasing $x$. This increase is not only related to the difference in ionic radii between $\mathrm{Ca}(1.12 \AA)$ [17] and $\mathrm{La}(1.16 \AA)$ [17] but also due to the degree of covalent character in bonds between the transition metal atom and the surrounding oxygen atoms [18]. This behaviour may play an important role in determining the atomic displacements and, hence, the lattice symmetry. A possible explanation of this effect may lie in the fact that the decrease of the -ve charge at A-site $\left(\mathrm{La}^{3+}\right.$ substituted $\left.\mathrm{Ca}^{2+}\right)$ and the increase of the -ve charge at the $\mathrm{B}$-site $\left(\mathrm{Fe}^{3+}\right.$ substituted $\left.\mathrm{Ti}^{4+}\right)$ may lead to a net decrease in the partial covalent character of the bonds involving oxygen ions and so the observed lattice expands (the average bond length Fe-O in Table (3)). 
Table(1): The lattice parameters, pesudo cubic lattice parameter $\left(a_{p}\right)$, and tolerance factor $(\mathrm{t})$.

\begin{tabular}{ccccccc}
\hline \hline parameter & $\mathrm{X}=0.0$ & $\mathrm{X}=0.1$ & $\mathrm{X}=0.2$ & $\mathrm{X}=0.3$ & $\mathrm{X}=0.4$ & $\mathrm{X}=0.5$ \\
\hline \hline $\mathrm{A}(\AA)$ & $5.38165(3)$ & $5.40000(2)$ & $5.41976(3)$ & $5.44042(2)$ & $5.45964(3)$ & $5.47827(3)$ \\
$\mathrm{B}(\AA)$ & $5.43855(3)$ & $5.45023(2)$ & $5.46246(3)$ & $5.47611(2)$ & $5.49021(3)$ & $5.50082(3)$ \\
$\mathrm{C}(\AA)$ & $7.64168(4)$ & $7.66250(3)$ & $7.68561(5)$ & $7.71020(4)$ & $7.73380(4)$ & $7.75613(5)$ \\
$\mathrm{a}_{\mathrm{p}}(\AA)$ & 3.8240 & 3.8350 & 3.8459 & 3.8581 & 3.8699 & 3.8805 \\
$\mathrm{t}$ & 0.9451 & 0.9697 & 0.9731 & 0.9765 & 0.9799 & 0.9833 \\
\hline \hline
\end{tabular}

The distortions in the perovskite structure with respect to the ideally cubic stable perovskite are controlled by the tolerance factor " $\mathrm{t}$ "

$$
\mathrm{t}=\left(\mathrm{r}_{\mathrm{A}}+\mathrm{r}_{\mathrm{O}}\right) / \sqrt{2}\left(\mathrm{r}_{\mathrm{B}}+\mathrm{r}_{\mathrm{O}}\right)
$$

where $r_{A}, r_{B}$ are the cation radii with 12 and 6 coordinated respectively, and $r_{O}$ is the oxygen anion radius in six fold coordination. For ideal cubic perovskite structure $t=1$, for distorted structure $t<1$. From the values of the tolerance factor tabulated in Table (1) it is clear, that $\mathrm{CaTiO}_{3}$ is more distorted than the substituted samples, i.e with increasing cation substitution the value of tolerance factor increases towards the ideal value and the degree of distortion decreases

From Table (1) it is clear that the orthorhombic unit cell parameters are related to the ideal cubic perovskite as $a \approx \sqrt{2} a_{p}, b \approx \sqrt{2} a_{p}$ and $c=2 a_{p}$, where $a_{p}$ is the lattice parameter of the ideal cubic perovskite. The value of the cell distortion $d$ of the system $\mathrm{Ca}_{1-\mathrm{x}} \mathrm{La}_{\mathrm{x}} \mathrm{Ti}_{1-\mathrm{x}} \mathrm{Fe}_{\mathrm{x}} \mathrm{O}_{3}, 0.0 \leq \mathrm{x} \leq 0.5$ is useful for estimating the departure from the ideal cubic cell cell given by the equation [19].

$$
d=\left[\left[\left((a / \sqrt{2})-a_{p}\right)^{2}+\left((b / \sqrt{2})-a_{p}\right)^{2}+(c / 2)^{2}\right] \times 10^{4}\right] / 3 a_{p} .
$$

Figure(4) represents the variation of the cell distortion factor versus the concentration of the substituted cations. From this Figure it is clear, that the cell distortion factor decreases with increasing the cation substitution. This experimental results agree with our calculated values of the tolerance factor.

It is clear, that from the refinable parameters of crystallite size of the investigated samples, disregarding the value of the sample $x=0.3$, that the crystallite size increases with increasing the substituted cations as shown in Figure (5), i.e. the crystallite increasing with decreasing the distortion. 


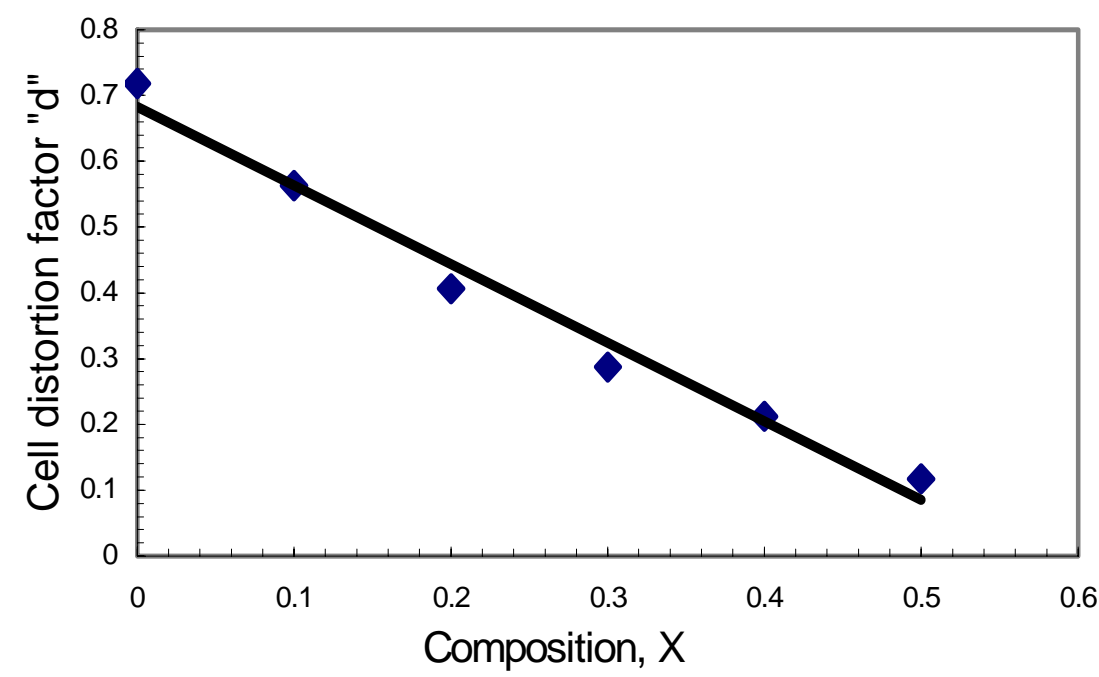

Fig.(4): The relation between cell distortion factor versus substituted cations.

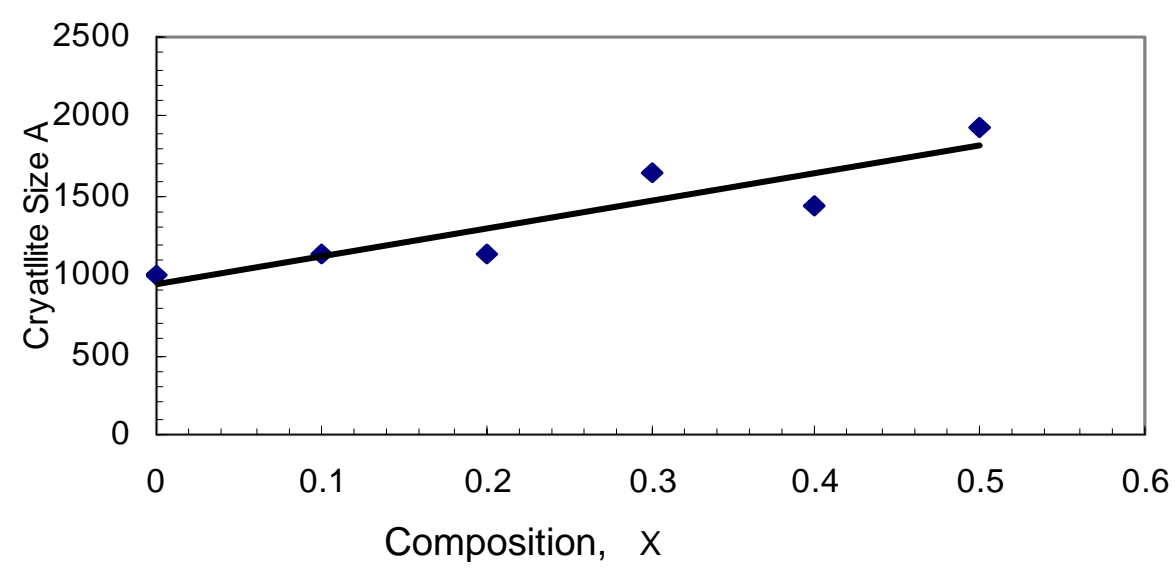

Fig.(5): The relation between crystallite size factor versus substituted cations.

\subsection{Atomic Coordinates:}

An examination of the refined atomic coordinates listed in Table (2) shows that $\mathrm{Ti}$ and $\mathrm{Fe}$ occupy the ideal special sites (4b) and the remaining atoms are only slightly displaced from their respective ideal positions. Cations in the A perovskite sites $(\mathrm{Ca} / \mathrm{La})$ and in the $\mathrm{B}$-ones $(\mathrm{Ti} / \mathrm{Fe})$ will be refered in the following discussion as $\mathrm{A}$ and $\mathrm{B}$, respectively. In order to study the distortion around the $\mathrm{Ti}$ and $\mathrm{Fe}$ atoms, which are surrounded by 6 oxygen ions forming octahedral coordination polyhedron, the interatomic distances, O-B-O angles and their standard deviations were calculated and listed in Table (4). As seen 
from this table there are three different B-O sets of bond lengths for each compound and their averages are in good agreement with the sum of Shannon ionic radii $(=2.05 \AA)$ [17]. Also, there are four different O-B-O angles showing a small deviation from the ideal angle $\left(90^{\circ}\right)$ of the cubic perovskite. These values of the intratomic distances and angles indicate, that the $\mathrm{BO}_{6}$ octahedra are quit distorted, which may be attributed not only to the different nature of the metal cations charge but also to the difference in the atomic radii between $\mathrm{Ti}$ and $\mathrm{Fe}$ that occupying these polyhedra.

Table(2): The refined atomic positions and temperature factors.

\begin{tabular}{|c|c|c|c|c|c|c|}
\hline $\mathrm{x}$ & Atom & Site & $\mathrm{x}$ & $\mathrm{y}$ & $\mathrm{Z}$ & $\mathrm{B}(\AA)$ \\
\hline \multirow[t]{4}{*}{0.0} & $\overline{\mathrm{Ca}}$ & $(4 c)$ & $-0.010(1)$ & 0.035 & 0.25 & $0.655(56)$ \\
\hline & $\mathrm{Ti}$ & (4b) & 0.5 & 0.0 & 0.0 & $0.572(56)$ \\
\hline & $\mathrm{O}_{1}$ & $(4 c)$ & $0.074(2)$ & $0.484(1)$ & 0.25 & $0.757(56)$ \\
\hline & $\mathrm{O}_{2}$ & $(8 d)$ & $0.288(2)$ & $0.288(1)$ & $0.033(1)$ & $0.749(56)$ \\
\hline \multirow[t]{4}{*}{0.1} & $\mathrm{Ca}, \mathrm{La}$ & $(4 c)$ & $-0.011(1)$ & 0.033 & 0.25 & $0.810(56)$ \\
\hline & $\mathrm{Ti}, \mathrm{Fe}$ & (4b) & 0.5 & 0.0 & 0.0 & $0.818(56)$ \\
\hline & $\mathrm{O}_{1}$ & $(4 c)$ & $0.065(3)$ & $0.489(2)$ & 0.25 & $0.716(56)$ \\
\hline & $\mathrm{O}_{2}$ & $(8 d)$ & $-0.287(2)$ & $0.286(2)$ & $0.034(1)$ & $0.634(56)$ \\
\hline \multirow[t]{4}{*}{0.2} & $\mathrm{Ca}, \mathrm{La}$ & $(4 c)$ & -0.009 & 0.028 & 0.25 & $0.929(63)$ \\
\hline & $\mathrm{Ti}, \mathrm{Fe}$ & (4b) & 0.5 & 0.0 & 0.0 & $0.936(63)$ \\
\hline & $\mathrm{O}_{1}$ & $(4 c)$ & $0.069(4)$ & $0.485(2)$ & 0.25 & $0.835(63)$ \\
\hline & $\mathrm{O}_{2}$ & $(8 d)$ & $-0.277(3)$ & $0.274(3)$ & $0.037(2)$ & $0.752(63)$ \\
\hline \multirow[t]{4}{*}{0.3} & $\mathrm{Ca}, \mathrm{La}$ & $(4 c)$ & -0.012 & 0.026 & 0.25 & $0.299(61)$ \\
\hline & $\mathrm{Ti}, \mathrm{Fe}$ & (4b) & 0.5 & 0.0 & 0.0 & $0.307(61)$ \\
\hline & $\mathrm{O}_{1}$ & $(4 c)$ & $0.071(4)$ & $0.487(3)$ & 0.25 & $0.205(61)$ \\
\hline & $\mathrm{O}_{2}$ & (8d) & $-0.276(3)$ & $0.274(3)$ & $0.020(4)$ & $0.123(61)$ \\
\hline \multirow[t]{4}{*}{0.4} & $\mathrm{Ca}, \mathrm{La}$ & $(4 c)$ & $-0.005(2)$ & 0.026 & 0.25 & $0.325(57)$ \\
\hline & $\mathrm{Ti}, \mathrm{Fe}$ & (4b) & 0.5 & 0.0 & 0.0 & $0.333(57)$ \\
\hline & $\mathrm{O}_{1}$ & $(4 c)$ & $0.079(6)$ & $0.486(3)$ & 0.25 & $0.231(57)$ \\
\hline & $\mathrm{O}_{2}$ & $(8 d)$ & $-0.284(4)$ & $0.282(3)$ & $0.035(3)$ & $0.148(57)$ \\
\hline \multirow[t]{4}{*}{0.5} & $\mathrm{Ca}, \mathrm{La}$ & $(4 c)$ & $-0.009(1)$ & 0.024 & 0.25 & $0.269(61)$ \\
\hline & $\mathrm{Ti}, \mathrm{Fe}$ & (4b) & 0.5 & 0.0 & 0.0 & $0.277(61)$ \\
\hline & $\mathrm{O}_{1}$ & $(4 c)$ & $0.106(5)$ & $0.493(4)$ & 0.25 & $0.175(61)$ \\
\hline & $\mathrm{O}_{2}$ & $(8 d)$ & $-0.275(6)$ & $0.275(5)$ & $0.016(5)$ & $0.093(61)$ \\
\hline
\end{tabular}

On other hand $\mathrm{Ca}$ and $\mathrm{La}$, located in the A-sites, are surrounded by twelve anions, eight of them are the first nearest neighbors located at a distance less than $3 \AA$ and the other four are the second nearest neighbors nearly above $3 \AA$ Table(3). But the A-site polyhedra can be defined as bicapped prisms, which related to cuboctahedral one by ignoring the second nearest neighbors located in four opposite edges in the unit cell. It is obvious also, that the displacement of the oxygen anions from their ideal positions produces a tilting 
of $\mathrm{BO}_{6}$ octahedra with respect to the cubic [010] and [ $\left[\begin{array}{ll}\overline{1} & 0\end{array}\right]$ directions $\bar{a} \bar{a} c$ according to the Glazer's notation [20,21]. Octahedral tilting brings about severe distortion of the $\mathrm{B}$ polyhedron, as a result of which $\mathrm{Ca}^{2+}$ and $\mathrm{La}^{3+}$ ions are 8 rather than 12 coordinated and the symmetry is orthorhombic space group Pbnm.

Table (3): The bond lengths and of the compounds $\mathrm{Ca}_{1-\mathrm{x}} \mathrm{La}_{\mathrm{x}} \mathrm{Ti}_{1-\mathrm{x}} \mathrm{Fe}_{\mathrm{x}} \mathrm{O}_{3}$.

\begin{tabular}{|c|c|c|c|c|c|c|}
\hline $\begin{array}{l}\text { Bond length } \\
(\AA)\end{array}$ & $X=0.0$ & $X=0.1$ & $X=0.2$ & $X=0.3$ & $X=0.4$ & $X=0.5$ \\
\hline$(\mathrm{Ca} / \mathrm{la})-\mathrm{O}_{2} \times 2$ & $2.621(1)$ & $2.620(1)$ & $2.567(2)$ & $2.655(2)$ & $2.654(2)$ & $2.707(4)$ \\
\hline $2 \times 2$ & ) & $2.679(1)$ & $2.760(2)$ & $2.678(3)$ & $.728(2)$ & $2.667(4)$ \\
\hline$(\mathrm{Ca} / \mathrm{La})-\mathrm{O}_{2} \times 2$ & $2.393(1)$ & $2.393(1)$ & $2.437(2)$ & $2.529(2)$ & $2.424(2)$ & $2.563(4)$ \\
\hline (Ca/La)-O1 & $2.483(1)$ & $2.522(1)$ & $2.531(1)$ & $2.560(1)$ & $2.546(2)$ & $2.656(2)$ \\
\hline$(\mathrm{Ca} / \mathrm{La})-\mathrm{O} 1$ & $2.365(1)$ & 2.42 & 2.39 & 2.41 & 2.33 & $2.208(3)$ \\
\hline$(\mathrm{Ca} / \mathrm{La})-\mathrm{O}_{1}$ & $3.030(1)$ & $2.990(1)$ & $2.998(1)$ & $2.990(1)$ & $3.562(2)$ & $3.281(3)$ \\
\hline$(\mathrm{Ca} / \mathrm{La})-\mathrm{O}_{1}$ & $3.045(1)$ & $3.000(2)$ & $3.045(1)$ & $3.047(2)$ & $3.141(3)$ & $2.989(2)$ \\
\hline$(\mathrm{Ca} / \mathrm{La})-\mathrm{O}_{2} \times 2$ & $3.169(2)$ & $3.187(2)$ & $3.164(2)$ & $3.080(2)$ & $3.198(2)$ & $3.064(4)$ \\
\hline$(\mathrm{Ti} / \mathrm{F}$ & & & & & & 1.9 \\
\hline$(\mathrm{Ti} / \mathrm{Fe}$ & $1.945(1)$ & $1.957(1)$ & 1.96 & 1.95 & $1.977(2)$ & $1.953(1)$ \\
\hline$(\mathrm{Ti}-/ \mathrm{Fe})-\mathrm{O}_{1} \times 2$ & $1.953(1)$ & $1.948(1)$ & $1.960(1)$ & $1.967(1)$ & $1.983(1)$ & $2.026(1)$ \\
\hline average & 1.952 & 1.954 & 1.957 & 1.953 & 1.976 & 1.978 \\
\hline
\end{tabular}

Table(4): The bond angles of the compounds $\mathrm{Ca}_{1-\mathrm{x}} \mathrm{La}_{\mathrm{x}} \mathrm{Ti}_{1-\mathrm{x}} \mathrm{Fe}_{\mathrm{x}} \mathrm{O}_{3}$.

\begin{tabular}{|c|c|c|c|c|c|c|}
\hline $\begin{array}{c}\text { Bond Angles } \\
\text { (degree) }\end{array}$ & $X=0.0$ & $X=0.1$ & $X=0.2$ & $X=0.3$ & $X=0.4$ & $X=0.5$ \\
\hline \multirow{4}{*}{$\mathrm{O}_{2}-\mathrm{Ti} / \mathrm{Fe}-\mathrm{O}_{2} \times 2$} & $990.44(6)$ & $90.51(7)$ & $\overline{990.74(10)}$ & $89.95(13)$ & $\overline{990.76(15)}$ & 90.01(22) \\
\hline & $89.56(6)$ & $89.49(7)$ & $89.26(10)$ & $90.05(13)$ & $89.24(13)$ & $89.99(20)$ \\
\hline & $88.48(5)$ & $90.16(6)$ & $89.49(9)$ & $85.73(12)$ & $88.52(12)$ & $82.21(18)$ \\
\hline & $91.52(5)$ & $89.84(7)$ & $90.51(9)$ & $94.37(13)$ & $91.48(14)$ & $97.79(20)$ \\
\hline $\mathrm{Ti} / \mathrm{Fe}-\mathrm{O}_{2}-\mathrm{Ti} / \mathrm{Fe}$ & $157.12(3)$ & $157.30(4)$ & $159.57(6)$ & $165.51(8)$ & $158.08(8)$ & $166.38(12)$ \\
\hline $\mathrm{Ti} / \mathrm{Fe}-\mathrm{O}_{1}-\mathrm{Ti} / \mathrm{Fe}$ & $156.02(1)$ & 159.01(1) & $157.29(2)$ & $157.05(2)$ & $154.5(3)$ & $146.35(3)$ \\
\hline
\end{tabular}

\section{Conclusions:}

1. The lattice parameter increases with increasing the substituted cations and this may be due to the difference in the ionic radius.

2. The tolerance factor decreases with increasing the substituted cations, i.e maximum distortion corresponding to $\mathrm{CaTiO}_{3}$. 
3. The cell distortion factor decreases with increasing the substituted cations, i.e. as the substitution increases it enhances the structure towards the ideal perovskite.

4. The crystallite size increase with decreasing the distortion .

\section{References:}

1. P. M. Woodward, Acta. Crystallogr., B53, 44 (1997).

2. H. F. Kay and B. C. Bailey, Acta. Crystallogr., 10, 219 (1957).

3. S. Sasaki, Acta Crytallogr., C43, 1668 (1987)

4. S. A. T. Redfern, J. Phys.: Condens. Matter, 8, 8267 (1996).

5. F. Guyot, P. Richet, Ph. Courtial and Ph. Gillet, Phys Chem Miner., 20, 141 (1993).

6. B. J. Kennedy, C. J. Howarad and B. C. Chakoumakos, J. Phys. Condens. Matter, 11, 1479 (1999).

7. A. I. Becerro, F. Seifert, R. J. Angel, S. Rios and McCammon, J. Phys. Condens. Matter, 12, 3661 (2000).

8. I.S. Kim, W. H. Jung, Y. Inaguma, I. Nkanura and M. Iath, Mater. Bull., 30(3), 307 (1995).

9. S. Neirman and I Burn, J. Mater. Sci., 19, 737 (1984).

10. U. Blalachandran and N. G. Eror, J. Mater. Sci., 23, 2676 (1988).

11. G. V. Lewis and C. R. A. Callow, J. Phys. Chem. Solids, 47, 89 (1986).

12. B. Jaffe, J.W.R. Cook and H. Jaffe, "Piezoelectric Ceramics" Academic Press, New York, Chapt. 5 (1971).

13. P. E. Werner "Treor, Trial and Error Program for Indexing Unknown Powder Patterns" University of Stockholm, S. 106, 91, Stockholm, Sweeden (1984).

14. J. Rodriguez-Carvajal Short Reference Guide of the FullProf Prog., Laboratory Leon Brillouin(CEA-CNRS), version July (2001).

15. W. G. Wyckoff "Crystal Structures" Interscience Publishers, Inc. New York Interscience Publishers LTD. London (1951) Vol II Chapter VIIA, p. 407.

16. P. Thompson, D. E. Cox and J. M. Hastings, J. Appl. Cryst., 20, 79 (1987).

17. R. D. Shannon, Acta. Crystallogr., A32, 751 (1976).

18. H. D. Megaw, Proc. Roy. Soc. A, 189, 261 (1947).

19. L. Vasylechko, L. Akselrud, A. Matkovskii, D. Sugak, A. Durygin and Z. Frukacz, J. Alloys and Compounds, 242, 18 (1996).

20. A. M. Glazers, Acta Crystallogr., B28, 3384 (1972).

21. A. M. Glazers, Acta Crystallogr., A31, 756 (1975). 